\title{
Advertisement call and genetic structure conservatism : good news for an endangered Neotropical frog
}

Lucas R Forti, William P Costa, Lucas B Martins, Carlos H L Nunes-de-Almeida, Luís Felipe Toledo

Background. Many amphibian species are negatively affected by anthropogenic habitat change. Populations distributed over modified landscapes may be subject to local extinction or may be relegated to remaining, likely isolated and possibly degraded, patches of available habitat. Isolation without gene flow can lead to variability in phenotypic traits due to differences in local selective pressures, such as environmental structure, microclimate or site-specific species assemblages.

Methods. Here we tested this microevolution hypothesis by evaluating the acoustic parameters of 349 advertisement calls from 15 males representing six populations of the endangered species Proceratophrys moratoi. In addition, we analyzed the genetic distance between populations and the genetic diversity by haplotype network. We carried out a cluster analysis by Bray-Curtis index of similarity using acoustic data by UPGMA method. We correlated acoustic dissimilarities (calculated by Euclidean distance) with geographic and genetic distances among populations.

Results. Spectral traits of the advertisement call of $P$. moratoi presented lower coefficients of variation than did temporal traits both within and among males. Cluster analyses placed individuals without population and geographical distance congruence, but recovered the species topology in relation to sister species. The genetic distance was low among populations: it did not exceed $0.4 \%$ for the most distant populations, and was not correlated with acoustic distance.

Discussion. Both acoustic features and genetic sequences are highly conserved, suggesting that populations may be connected by recent migrations or that they are subject to stabilizing selective forces. Although future studies are needed, these findings contribute to a growing body of literature suggesting that this species would be a good candidate for a reintroduction program without negative effects on communication or even genetic heritage. 


\section{Advertisement call and genetic structure conservatism: good news for an}

2 endangered Neotropical frog

3

4 Lucas R.Forti ${ }^{1,5}$, William P. da Costa $^{2}$, Lucas B. Martins ${ }^{3,4}$, Carlos H. L. Nunes-de-Almeida ${ }^{1}$ and 5 Luís Felipe Toledo ${ }^{1}$

6

$7 \quad{ }^{1}$ Laboratório Multiusuário de Bioacústica (LMBio) e Laboratório de História Natural de

8 Anfíbios Brasileiros (LaHNAB), Departamento de Biologia Animal, Instituto de Biologia,

9 Universidade Estadual de Campinas, Caixa Postal 6109. CEP 13083-970, Campinas, São Paulo, 10 Brazil.

$11{ }^{2}$ Departamento de Biologia Estrutural e Funcional, Instituto de Biologia, Universidade Estadual 12 de Campinas (UNICAMP). CEP 13083-863, Campinas, SP, Brazil.

$13{ }^{3}$ Universidade Federal de Uberlândia, Faculdade de Ciências Integradas do Pontal, Laboratório 14 de Taxonomia, Sistemática e Ecologia de Anuros Neotropicais. Rua 20, 1600 - Bairro Tupã, 15 38304-402, Ituiutaba, Minas Gerais, Brazil.

$16{ }^{4}$ Universidade de São Paulo, FFCLRP/Departamento de Biologia, Programa de Pós-Graduação 17 em Biologia Comparada. Avenida dos Bandeirantes, 3900. 14040-901. Ribeirão Preto, São

18 Paulo, Brazil.

195 Corresponding author: e-mail: lucas_forti@yahoo.com.br 
21 ABSTRACT

22 Background. Many amphibian species are negatively affected by habitat change due to anthropogenic activities. Populations distributed over modified landscapes may be subject to local extinction or may be relegated to the remaining — likely isolated and possibly degradedpatches of available habitat. Isolation without gene flow could lead to variability in phenotypic traits owing to differences in local selective pressures such as environmental structure, microclimate, or site-specific species assemblages.

Methods. Here, we tested the microevolution hypothesis by evaluating the acoustic parameters of 349 advertisement calls from 15 males from six populations of the endangered amphibian species Proceratophrys moratoi. In addition, we analyzed the genetic distance among populations and the genetic diversity by the haplotype network. We performed cluster analysis on acoustic data based on the Bray-Curtis index of similarity, using the UPGMA method. We correlated acoustic dissimilarities (calculated by Euclidean distance) with geographical and genetic distances among populations.

Results. Spectral traits of the advertisement call of $P$. moratoi presented lower coefficients of variation than did temporal traits, both within and among males. Cluster analyses placed individuals without congruence in population or geographical distance, but recovered the species topology in relation to sister species. The genetic distance among populations was low; it did not exceed $0.4 \%$ for the most distant populations, and was not correlated with acoustic distance.

Discussion. Both acoustic features and genetic sequences are highly conserved, suggesting that populations could be connected by recent migrations, and that they are subject to stabilizing selective forces. Although further studies are required, these findings add to a growing body of literature suggesting that this species would be a good candidate for individuals reintroduction program without negative effects on communication or genetic heritage. 


\section{INTRODUCTION}

The greatest threat to endangered amphibians is habitat change caused by anthropogenic activities, which alters resource availability, environmental quality, and ecological processes (Metzger, 2001; Stuart et al., 2004). Such negative impacts have important implications for organisms that face new selective pressures exerted by habitat conversion (Forman, 1995). In addition, habitat fragmentation causes isolation of populations, and places them at risk of extinction towing to demographic stochasticity, genetic depression, social dysfunction, and exogenous factors such as strong climatic variations and disasters (Simberloff, 1986). Therefore, it is predicted that species affected by these changes would (1) migrate to appropriate adjacent areas; (2) undergo local decline and extinction; or (3) undergo local adaptation.

Surprisingly, several species thrive in modified sites even after profound anthropogenic transformation. Because these landscapes often exhibit physical, climatic, and biological (e.g., species assemblage) shifts, the ability of the remaining species to persist is likely a consequence of phenotypic plasticity in traits such as behavior, morphology, and reproduction (Mayr, 1963; Pulido \& Berthold, 2004; Merckx \& Dyck, 2006).

One of the most important phenotypic traits in evolutionary studies of anurans is the male advertisement call, because components of these calls are fundamental to species recognition and mate choice, and are thus under sexual selection (Ryan, 1991; Wycherley, Doran \& Beebee, 2002; Smith, Osborne \& Hunter, 2003; Kaefer \& Lima, 2012; Grenat, Valetti \& Martino, 2013). Moreover, calls are subject to natural selection over larger geographic ranges, mainly when populations are isolated by physical barriers (Simões et al., 2008; Kaefer, Tsuji-Nishikido \& Lima, 2012; Tsuji-Nishikido et al., 2012). Because anurans tend to not disperse over long distances (Blaustein, Wake \& Sousa, 1994; Tozetti \& Toledo, 2005; Lougheed et al., 2006), sexual phenotypic traits in anurans are likely influenced by local environmental conditions (Bosch \& de la Riva, 2004; Ey \& Fischer, 2009).

The anuran advertisement call is a multidimensional signal that can be viewed as a collection of spectral and temporal acoustic traits that are influenced, for example, by body size, air temperature, and social context (Wells \& Taigen, 1986; Gerhardt, 1991; Bee, 2002; Gerhardt \& Huber, 2002; Wong et al., 2004; Toledo et al., 2015a). Therefore, sexual selection, habitat structure, and climatic conditions might all cause variation in call traits among populations (Jang et al., 2011; Faria et al., 2009 Kaefer \& Lima, 2012; Kaefer, Tsuji-Nishikido \& Lima, 2012; 
Narins \& Meenderink, 2014). In addition, other biotic processes, such as interspecific acoustic interactions, which generate distinctive background noise, can affect call variation among populations (Littlejohn, 1976; Höbel \& Gerhardt, 2003).

Different traits of advertisement calls may have distinct roles in anuran communication, and therefore, may evolve by distinct selective pressures (Cocroft \& Ryan, 1995; Erdtmann \& Amézquita, 2009; Goicoechea, De La Riva \& Padial, 2010). As a result, call traits should vary in unique and predictable ways. Gerhardt (1991) classified these traits as static or dynamic acoustic traits. Typically, spectral acoustic traits show low variability (static) and are related to conspecific recognition. Consequently, static traits are subject to stabilizing or weakly directional selection by female choice. On the other hand, most temporal acoustic traits show higher variability (dynamic) and are thought to indicate a male's investment in reproduction; these may be subject to directional selection by females for values above species means (Gerhardt, 1991; Gerhardt \& Bee, 2007).

However, acoustic variation is not always related to genetic variation at the population level (Heyer \& Reid, 2003; Lougheed et al., 2006; Kaefer et al., 2013). In these cases, despite some phylogenetic signal being recorded in vocalizations (Erdtmann \& Amézquita, 2009; Goicoechea, De La Riva \& Padial, 2010; Tobias, Evans \& Kelley, 2011; Gingras et al., 2013), the evolution of genotypes and phenotypes (as acoustic traits) may be decoupled (Lougheed et al., 2006) or asynchronous (Kaefer et al., 2013).

Herein, we speculated that historical modification of landscapes by agricultural crops has created barriers among persistent populations, and affected phenotypic and genetic traits in an endangered Neotropical toad, Proceratophrys moratoi. We tested the hypothesis that unique selective pressures among these remaining populations have led to divergence in acoustic traits and increased genetic structure.

\section{METHODS}

\section{Species}

The genus Proceratophrys includes 40 South American toad species (Frost, 2015). Proceratophrys moratoi, originally described in the genus Odontophrynus (Jim \& Caramaschii, 1980), is a member of the $P$. cristiceps species group (Giaretta et al., 2000), lacking palpebral appendages and postocular swellings. It was described from the municipality of Botucatu, state 
109

110

111

112

113

114

115

116

117

118

119

120

121

122

123

124

125

126

127

128

129

130

131

132

133

134

135

136

137

138

139

of São Paulo (Jim \& Caramaschii, 1980), from where it is now extirpated (Brasileiro, Martins \& Jim, 2008). Despite recent reports of new populations outside Botucatu (Brasileiro, Martins \& Jim, 2008; Rolim et al., 2010; Maffei, Ubaid \& Jim, 2011; Martins \& Giaretta 2012), according to the current Brazilian red list, the species is endangered (EN) (MMA, 2014).

Proceratophrys moratoi is endemic to the Brazilian Cerrado and is found in open grasslands near small streams or swamps (Rolim et al., 2010; Maffei, Ubaid \& Jim, 2011; Martins \& Giaretta, 2012). Males call during the rainy season (generally from October to February). The advertisement call of $P$. moratoi is characterized by a single train of regularly repeated pulses. Call duration is approximately $250 \mathrm{~ms}$, and the frequency ranges from 700 to 1900 Hz (Brasileiro, Martins \& Jim, 2008; Martins \& Giaretta, 2012).

\section{Sites}

We studied six populations of $P$. moratoi, which represent almost its entire known geographic distribution (Martins \& Giaretta, 2012). We sampled the populations in two southeastern Brazilian states (Figure 1): São Paulo (Avaré, Bauru, Itirapina and São Carlos) and Minas Gerais (Ituiutaba and Uberlândia). These regions represent an important center of agricultural and livestock production (MMA, 2005) with a remarkable history of land use modification and natural habitat devastation (Dean, 1995). With the exception of the populations from Itirapina, Bauru, and Uberlândia, which were in protected natural reserves, all populations inhabited modified landscapes.

\section{Acoustic analyses}

We analyzed 349 calls from 15 males of $P$. moratoi from 6 localities, 18 calls from 2 males of Odontophrynus americanus and 6 calls from one male of Proceratophrys boiei. Calls were recorded using the following combinations of microphones and recorders: (1) an Audiotechnica AT 835b microphone and a Marantz PMD-222 recorder, (2) a Dynamic microphone and an Uher 4000 recorder, (3) a Sennheiser ME67/K6 microphone and a Boss 864 recorder, (4) a Sennheiser ME67/K6 microphone and a Marantz PMD671 recorder, or (5) a Sennheiser ME66/K6 microphone and an M-audio Microtrack II recorder. All recordings were made with sample rate of 44.1 or $48 \mathrm{kHz}$, and at 16-bit resolution. Acoustic recordings used in the present study are available in the Fonoteca Neotropical Jacques Vielliard, with collection 
numbers FNJV 10498, 10577, 12222-24, 12228, the Smithsonian Institution website (http://vertebrates.si.edu/herps/frogs_boraceia/list.htm), and the personal collection of Ariovaldo A. Giaretta, which are detailed in the appendix of Martins \& Giaretta (2012).

Acoustic analyses were performed in Raven Pro 641.4 for Windows (Cornell Lab of Ornithology), with the following settings: FFT (Fast Fourier Transformation $)=1024$; Overlap $=$ 50 for spectral evaluations; and FFT $=256$ and Overlap $=50$ for temporal variables. Both temporal and spectral values were extracted from the spectrogram. We analyzed the following quantitative traits: frequency range, maximum frequency, minimum frequency, peak of dominant frequency, call duration, number of pulses per note, and pulse rate (pulses per second). Spectral measurements were obtained by selecting four variables in the source "choose measurements" in Raven: (1) Frequency 5\% (Hz); (2) Frequency 95\% (Hz) - these two measures include maximum frequency and minimum frequency, ignoring $5 \%$ below and above the total energy in the selected call; (3) Bandwidth $90 \%(\mathrm{~Hz})$ - frequency range that included $90 \%$ of the energy distribution, i.e., the difference between Frequency 95\% and Frequency 5\%; (4) Max Frequency $(\mathrm{Hz})$ - peak of dominant frequency (the frequency in which the power is maximum within the call). For temporal properties, we made precise selections on calls in the spectrogram, and visually counted the pulses.

We calculated the variation in quantitative acoustic variables through coefficient of variation $(\mathrm{CV} ; \mathrm{SD} /$ mean) for both among-males and within-males level. As defined by Gerhardt (1991), CVs can be used to determine if a call trait is static ( $C V<5 \%$ within males and $<12 \%$ among males) or dynamic ( $\mathrm{CV}>12 \%$ within males and among males).

\section{Genetic analyses}

Liver and muscle samples from 26 P. moratoi individuals from six populations were collected: four populations in the state of São Paulo: Itirapina $(\mathrm{n}=5)$, São Carlos $(\mathrm{n}=5)$, Bauru $(\mathrm{n}=5)$, and Avaré $(\mathrm{n}=2)$; and two populations in the state of Minas Gerais: Ituiutaba $(\mathrm{n}=4)$ and Uberlândia ( $(=5)$. This small sample size is in part attributable to the rarity of the species, and collection restrictions, as it is endangered and apparently extinct in at least two populations. Tissues were preserved in 95\% ethanol. Voucher specimens were deposited in the Coleção Científica Jorge Jim indexed in Museu Nacional, Rio de Janeiro, Brazil (CCJJ 7925, 7928-7938, 7944, 7950-7952, 7958). Tissue collection can be found in the Collection of tissue and 
171 chromosome preparation Shirlei Maria Recco Pimentel, Universidade Estadual de Campinas

172 (UNICAMP), Campinas, São Paulo, Brazil (SMRP 469.01-469.14, 469.26-469.42). Total

173 genomic DNA was extracted according to Veiga-Menocello et al. (2014). We targeted a 650-bp

174 region of the 16S mitochondrial gene using the primers 16Sar and 16Sbr (Palumbi et al., 1991).

175 Fragments were purified using a purification kit (GE Healthcare Life Science, São Paulo, SP,

176 Brazil); sequences were obtained using the same primers and BigDye ${ }^{\mathrm{TM}} 3.1$ cycle sequencing

177 kits (Applied Biosystems Foster City, CA, USA), and were read on an ABI 3700/Prism.

178 Sequences were checked by eye using BioEdit v.5.0.9 and aligned with Muscle (Edgar, 2004).

179 Genetic distances ( $p$ distances) were computed from mitochondrial loci using MEGA 5.1

180 (Tamura et al., 2011).

181 We verified haplotypes using DnaSP v. 5.10 .01 (Librado \& Rozas 2009). We obtained a

182 haplotype network using the Median-joining network method (Bandelt, Forster \& Rohl, 1999)

183 with NETWORK 4.6.1.2.

184

185

Statistical analyses

186

We performed cluster analyses based on acoustic similarities using the Bray-Curtis index, through the UPGMA method and bootstrap with 1000 randomizations (see Toledo et al., 2015b).

188 We calculated the values for Euclidean distance among populations for acoustic traits, and 189 correlated them with the values for geographical and genetic distance through Mantel tests with 1000 permutations. Geographical distance was estimated in Google Earth as the straight-line distance between two sites. We conducted statistical analyses in Past 2.17 (Hammer, Harper \& Ryan, 2001)

\section{RESULTS}

\section{Acoustic similarities and variability}

The structure of calls from all individuals presented the same pattern of a single periodic pulse train (Figure 2a). However, we found slight differences in spectral and temporal traits among calls from distinct localities (Table 1). Male calls from Avaré had the lowest frequencies, whereas calls from Ituiutaba had the highest frequencies. The individual from São Carlos presented the longest calls, whereas the individual from Bauru emitted the shortest calls. Males 
202 the lowest pulse rate. Temporal traits of the advertisement call presented high coefficients of

203 variation among males (above 12\%), and were considered dynamic (Figure 2b). Among the

204 spectral traits, frequency range showed the highest coefficient of variation among males, whereas

205 the other three spectral traits presented an intermediate variation (between 5 and 12\%; Figure

206 2b). All call traits presented low variation within males, with CVs of lower than 8\% (Figure 2c),

207 and the majority was considered static, with $<5 \%$ variation.

208 Cluster analysis placed $O$. americanus and $P$. boiei as outgroups in relation to the focal $P$.

209 moratoi individuals (Figure 3). Individuals were not grouped by population, except for the males

210 from Itirapina. The male from Avaré had the most distinct call, and was grouped with two

211 individuals from Uberlândia. However, other males from Uberlândia were placed in the other

212 two major groups, and individuals were not organized according to geographical distance among

213 populations. This was confirmed by the absence of a correlation between geographical distance

214 and the acoustic distance between populations $(\mathrm{r}=-0.23 ; P=0.73)$.

215

216

\section{Haplotype network and genetic distance}

217

We found 7 haplotypes in the 26 partial sequences of the mitochondrial $16 \mathrm{~S}$ gene (Figure

218

4). Most haplotypes (H1-H4) were shared among multiple populations, but three haplotypes

219

(H5-H7) were found in one individual each, and were limited to Uberlândia (H5, H6) or

220

Ituiutaba (H7). Genetic distances of $P$. moratoi averaged $0.2 \%(0.0-0.4)$ between populations

221

(Table 2) and $0.25 \%(0.0-0.5)$ within populations. Acoustic and geographical distance between

222 populations was not correlated with genetic distance $(\mathrm{r}=-0.32 ; P=0.86 ;$ and $\mathrm{r}=-0.32 ; \mathrm{P}=$

223 0.87).

224

\section{DISCUSSION}

In the present study, we found a common structural pattern (a single periodic pulse train;

227

228

229

230

231

232
Fig. 1) for all individuals, which is consistent with the findings of previous reports on the advertisement call of P. moratoi (Brasileiro, Martins \& Jim, 2008; Martins \& Giaretta, 2012).

The variability in the advertisement call of $P$. moratoi follows a general pattern among anurans; spectral traits exhibit lower variation than do temporal ones, with the exception of frequency range (Gerhardt, 1991; Gerhardt \& Huber, 2002). The low coefficients of variation in call traits we observed among males (showing highly stereotyped signals) could be attributed to 
233 stabilizing selection (Kaefer \& Lima, 2012; Kaefer, Tsuji-Nishikido \& Lima, 2012), which is

234 usually a result of generalized female choice (Jennions \& Petrie, 1997). Alternatively, it could

235 reflect the absence of selection and the presence of neutral/stochastic processes (Edrtmann \&

236 Amézquita, 2009; Kaefer et al., 2013; Toledo et al., 2015b). Because sexual signals carry

237 important information for mate recognition (Ryan, 1991), spectral traits would not be expected to

238 diverge rapidly. Temporal traits, which are generally dynamic, have been shown to vary with

239 social or environmental conditions (Bosch \& de la Riva, 2004; Ey \& Fischer, 2009). For

240 example, some species respond to vocal interactions and chorus composition with rapid temporal

241 adjustments in their calling behavior (Schwartz, 2001). Therefore, temporal traits such as pulse

242 rate and call duration may be affected by social context. In species wherein females make

243 choices based on temporal traits alone (Littlejohn, 1965), these temporal traits would be

244 predicted to minimize the patterns observed in spectral traits. However, we observed that mate

245 choice by acoustic properties remains to be tested, since we do not know how female P. moratoi

246 individuals select males.

247 Habitat structure, background noise, and other environmental differences are pivotal in

248 the evolution of acoustic communication in frogs (Goutte, Dubois \& Legendre, 2013; Schwartz

$249 \&$ Bee, 2013). These factors certainly contribute to regional divergence in call traits among

250 individuals (Amézquita et al. 2006). Each reproductive environment could present distinct

251 species composition and considerably different acoustic qualities. Based on this ecophenotypic

252 hypothesis, we expected that local pressures would modulate call features in P. moratoi males

253 from distinct localities, because populations of this threatened species surrounded by human-

254 transformed landscapes could show low connectivity. In contrast, cluster analyses failed to group

255 individuals by population (geographical context). Taken together, these results indicate minimal

256 pressure for signal divergence, which could be explained by the following, non-exclusive

257 hypotheses: (1) the reproductive environment in the sampled localities is similar with respect to

258 habitat structure and background noise; (2) the female choice drives stable selection, which

259 equalizes the general acoustic features of males from different localities; (3) the populations

260 were recently connected, presenting traces of recent genetic flow; and (4) random evolutionary

261 processes act on the calls (Toledo et al., 2015b). We did not test these hypotheses, but it is

262 unlikely that populations were recently connected, as genetic distance was not correlated with

263 acoustic distance among populations. Furthermore, although some studies have reported a 
264 correlation between genetic and acoustic distances (Smith, Osborne \& Hunter, 2003; Amézquita 265 et al., 2009), many others have shown that geographical variation in sexual signals and genetic 266 distances among populations do not co-vary (Heyer \& Reid, 2003; Lougheed et al., 2006; Pröhl 267 et al., 2007). In these cases, it is possible that evolution has been decoupled for genotypic and 268 phenotypic features (Lougheed et al., 2006). Cluster analysis demonstrated that a phylogenetic 269 signal in anuran advertisement call (as a phenotypic trait) might not evolve as rapidly as DNA 270 differences appear, a finding corroborated by Kaefer et al. (2013). Consequently, our results 271 suggest that a phylogenetic signal would be apparent only when higher taxonomic levels are 272 compared, for example, different species, genera, or families. This finding could be explained, in 273 part, by the conservative nature of the molecular marker used - the $16 \mathrm{~S}$ gene — which is 274 commonly employed to separate different species (Fouquet et al. 2007; Brusquetti et al. 2014; 275 Yang et al., 2014; Lourenço et al. 2015).

Although our dataset is limited, we observed that acoustic and genetic variation appears to be conserved among individuals distributed across human-altered landscapes. Our preliminary results showed similar call types and genotypes (also presenting low genetic divergence) among different populations. Such reduced acoustic and possible genetic structure could be considered in future conservation actions; for example, these findings suggest that communication barriers (prezygotic) would pose no obstacle to reproduction (Dobzhansky, 1951; Tucker \& Gerhardt, 2011) if a reintroduction program were initiated for this species. Nevertheless, playback experiments are required for testing this hypothesis first. From the genetic point of view, if the actual molecular marker used in the present study could represent the genomes of all individuals, the genetic barrier (postzygotic) would pose no obstacle to reproduction too (Dobzhansky, 1951; Tucker \& Gerhardt, 2011). The type locality of this species (Botucatu) is still preserved, and a reintroduction could be considered after complementary genetic, natural history, and experimental research. The causes of the decline of this population are unknown, and therefore, a reintroduction initiative could also aid in understanding past decline (if the cause is still active) and help to prevent further decline here (for example, of Bokermannohyla izecksohni-another species that could be threatened in Botucatu; L. F. Toledo \& C. Z. Torres, unpublished data) and elsewhere. Thus, the findings of the present study add to the growing body of literature supporting $P$. moratoi as a potential candidate for conservation actions, although additional work 294 is necessary before an action plan could be initiated 


\section{ACKNOWLEDGMENTS}

297

298

299

300

301

302

303

304

305

306

307

308

309

310

311

312

313

314

315

316

317

318

319

320

321

322

323

Ariovaldo A. Giaretta helped in fieldwork and recorded specimens in Uberlândia and Ituiutaba. We are grateful to Luciana B. Lourenço and Shirlei M. Recco-Pimentel for their support in genetic analysis. Pertinent comments and English language review were provided by Kristine Kaiser from the Society for the Study of Amphibians and Reptiles (SSAR).

\section{REFERENCES}

Amézquita A, Hödl W, Castellanos L, Lima AP, Erdtmann L, de Araújo MC. 2006. Masking interference and the evolution of the acoustic communication system in the Amazonian dendrobatid frog Allobates femoralis. Evolution 60: 1874-1887.

Amézquita A, Lima AP, Jehle R, Castellanos L, Ramos O, Crawford AJ, Gasser H, Hödl W. 2009. Calls, colours, shapes, and genes: A multi-trait approach to the study of geographic variation in the Amazonian frog Allobates femoralis. Biological Journal of the Linnean Society 98:826-838.

Bandelt HJ, Forster P, Rohl A. 1999. Median-joining networks for inferring intraspecific phylogenies. Molecular Biology and Evolution 16:37-48.

Bee MA. 2002. Territorial male bullfrogs (Rana catesbeiana) do not assess fighting ability based on size related variation in acoustic signals. Behavioral Ecology 13(1):109-124.

Blaustein AR, Wake DB, Sousa WP. 1994. Amphibian declines: judging stability, persistence, and susceptibility of populations to local and global extinctions. Conservation Biology 8:6071.

Bosch, J, De la Riva I. 2004. Are frog calls modulated by the environment? An analysis with anuran species from Bolivia. Canadian Journal of Zoology 82:880-888.

Brasileiro CA, Martins IA, Jim J. 2008. Amphibia, Anura, Cycloramphidae, Odontophrynus moratoi: Distribution extension and advertisement call. Check List 4:382-385.

Brusquetti F, Jansen M, Barrio-Amorós C, Segalla M, Haddad CF. 2014. Taxonomic review of Scinax fuscomarginatus (Lutz, 1925) and related species (Anura; Hylidae). Zoological Journal of the Linnean Society, 171. 4:783-821.

Cocroft RB, Ryan, MJ. 1995. Patterns of advertisement call evolution in toads and chorus frogs. Animal Behaviour 49:283-303. 
325 326

327

328

329

330

331

332

333

334

335

336

337

338

339

340

341

342

343

344

345

346

347

Dean, WB. 1995. With broadax and firebrand: the destruction of the Brazilian Atlantic Forest. Berkeley: University of California Press.

Dobzhansky T. 1951. Genetics and the origin of species. New York: Columbia University Press.

Edgar RC. 2004. Muscle: multiple sequence alignment with high accuracy and high throughput. Nucleic Acids Research 32(5):1792-1797.

Erdtmann L, Amézquita A. 2009. Differential evolution of advertisement call traits in dartpoison frogs (Anura: Dendrobatidae). Ethology 115:801-811.

Ey E, Fischer J. 2009. The "acoustic adaptation hypothesis"- A review of the evidence from birds, anurans and mammals. Bioacoustics 19:21-48.

Faria DC, Signorelli C, Morais LAR, Bastos RP, Maciel NM. 2009. Geographic structure and acoustic variation in populations of Scinax squalirostris (A. Lutz, 1925) (Anura: Hylidae). North-Western Journal of Zoology 9:131514.

Forman, RTT. 1995. Land Mosaics: The Ecology of Landscapes and Regions. Cambridge: Cambridge University Press.

Fouquet A, Gilles A, Vences M, Marty C, Blanc M, Gemmell NJ. 2007. Underestimation of species richness in Neotropical frogs revealed by mtDNA analyses. PLoS one, 2. 10: e1109.

Frost, DR. 2015. Amphibian Species of the World: an Online Reference. Version 6.0 (September, 14). Available at http://research.amnh.org/herpetology/amphibia/index.html. (accessed 30 September 2011).

Gerhardt HC. 1991. Female mate choice in treefrogs: static and dynamic acoustic criteria. Animal Behaviour 42:615-635.

Gerhardt HC, Huber F. 2002. Acoustic communication in insects and anurans: common problems and diverse solutions. Chicago and London: The University of Chicago Press.

Gerhardt HC, Bee MA. 2007. Recognition and localization of acoustic signals. — In: Hearing and sound communication in amphibians (Narins, P.M., Feng, A.S., Fay, R.R. \& Popper, A.N., eds). Springer, New York, NY, p. 113-146.

Giaretta AA, Bernarde PS, Kokubum MCN. 2000. A new species of Proceratophrys (Anura: Leptodactylidae) from the Amazon Rain Forest. Journal of Herpetology 34(2):173-178.

Goicoechea N, De La Riva I, Padial JM. 2010. Recovering phylogenetic signal from frog mating calls. Zoologica Scripta 39:141-154. 
356 Goutte S, Dubois A, Legendre F. 2013. The Importance of Ambient Sound Level to Characterise 357 Anuran Habitat. PLoS ONE 8(10):e78020.

358 Grenat PR, Valetti JA, Martino AL. 2013. Intra-specific variation in advertisement call of 359 Odontophrynus cordobae (Anura, Cycloramphidae): a multilevel and multifactor analysis. 360 Amphibia-Reptilia 34:471-482.

361 Gingras B, Mohandesan E, Boko D, Fitch WT. 2013. Phylogenetic signal in the acoustic 362 363 parameters of the advertisement calls of four clades of anurans. BMC Evolutionary Biology, 13:134.

364

365

366

367

368

369

370

371

372

373

374

375

376

377

378

379

380

381

382

383

384

385

Hammer O, Harper D, Ryan P. 2001. PAST: Paleontological Statistics Software for education and data analysis. Paleontología Electrónica 4:1-9.

Heyer WR, Reid YR. 2003. Does advertisement call variation coincide with genetic variation in the genetically diverse frog taxon currently known as Leptodactylus fuscus (Amphibia: Leptodactylidae)? Anais da Academia Brasileira de Ciências 75(1):39-54.

Höbel G, Gerhardt HC. 2003. Reproductive character displacement in the acoustic communication system of green tree frogs (Hyla cinerea). Evolution 57:894-904.

Jang Y, Hahm EH, Lee H, Park S, Won Y, Choe JC. 2011. Geographic Variation in Advertisement Calls in a Tree Frog Species: Gene Flow and Selection Hypotheses. PLoS ONE 6(8):1-12.

Jennions MD, Petrie M. 1997. Variation in mate choice and mating preferences: a review of causes and consequences. Biological Reviews 72: 283-327.

Jim J, Caramaschi U. 1980. Uma nova espécie de Odontophrynus da região de Botucatu, São Paulo, Brasil (Amphibia, Anura). Revista Brasileira de Biologia 40:357-360.

Kaefer IL, Lima AP. 2012. Sexual signals of the Amazonian frog Allobates paleovarzensis: Geographic variation and stereotypy of acoustic traits. Behaviour 149:15-33.

Kaefer IL, Tsuji-Nishikido BM, Lima AP. 2012. Beyond the river: underlying determinants of population acoustic signal variability in Amazonian direct-developing Allobates (Anura: Dendrobatoidea). Acta Ethologica 15:187-194.

Kaefer IL, Tsuji-Nishikido BM, Mota EP, Farias IP, Lima AP. 2013. The Early Stages of Speciation in Amazonian Forest Frogs: Phenotypic Conservatism Despite Strong Genetic Structure. Evolutionary Biology 40:228-245. 
386 387

388

389

390

391

392

393

394

395

396

397

398

399

400

401

402

403

404

405

406

407

408

409

410

411

412

413

414

415

416

Librado P, Rozas J. 2009. DnaSP v5: a software for comprehensive analysis of DNA polymorphism data. Bioinformatics 25:1451-1452.

Littlejohn MJ. 1965. Premating isolation in the Hyla ewingi complex (Anura: Hylidae). Evolution 19:234-243.

Littlejohn MJ. 1976. The Litoria ewingi complex (Anura: Hylidae) in south-eastern Australia IV. Variation in mating-call structure across a narrow hybrid zone between $L$. ewingi and $L$. paraewingi. Australian Journal of Zoology 24:283-293.

Lougheed SC, Austin JD, Bogart JP, Boag PT, Chek AA. 2006. Multi-character perspectives on the evolution of intraspecific differentiation in a neotropical hylid frog. BMC Evolutionary Biology 6:23.

Lourenço LB, Targueta CP, Baldo D, Nascimento J, Garcia PC, Andrade GV, Haddad CF Recco-Pimentel SM. 2015. Phylogeny of frogs from the genus Physalaemus (Anura, Leptodactylidae) inferred from mitochondrial and nuclear gene sequences. Molecular phylogenetics and evolution, 92: 204-216.

Maffei F, Ubaid FK, Jim J. 2011. Discovery of the fifth population of a threatened and endemic toad of the Brazilian Cerrado, Proceratophrys moratoi (Anura, Cycloramphidae). Herpetology Notes 4:95-96.

Martins LB, Giaretta AA. 2012. Advertisement call of two species of Proceratophrys (Anura: Odontophrynidae) from Minas Gerais, Brazil, with comments on their distribution, taxonomy and conservation status. South American Journal of Herpetology 7:203-212.

Mayr E. 1963. Populations, species and evolution. Cambridge: Harvard University Press.

Merckx T, Dyck HV. 2006. Landscape structure and phenotypic plasticity in flight morphology in the butterfly Pararge aegeria. Oikos 113:226-232.

Metzger JP. 2001. O que é ecologia de paisagens? Biota Neotropica 1(1 and 2):1-9.

Ministério do Meio Ambiente - MMA. 2005. Cem anos de devastação: revisitada 30 anos depois. Secretaria de Biodiversidade e Florestas: Victor MAM et al. - Brasília.

Ministério do Meio Ambiente - MMA. 2014. Lista das Espécies da Fauna Brasileira Ameaçadas de Extinção. Portaria $n^{\circ}$ 444, de 17 de dezembro de 2014. Brasília, DF: Diário Oficial da República Federativa do Brasil.

Narins PM, Meenderink SWF. 2014. Climate change and frog calls: long-term correlations along tropical altitudinal gradient. Proceedings of the Royal Society B 281: 20140401. 
417 Palumbi SR, Martins A, Romano S, Mc-Millan WO, Stice L, Grabawski G. 1991. The simple

418 fool's guide to PCR, version 2.0. Honolulu: Privately published.

419 Pulido F, Berthold P. 2004. Microevolutionary Response to Climatic Change. Advances in $420 \quad$ Ecological Research 35:151-183.

421 Pröhl H, Hagemann S, Karsch J, Höbel G. 2007. Geographic variation in male sexual signals in 422 strawberry poison frogs (Dendrobates pumilio). Ethology 113:825-837.

423

Rolim DC, Martinez RAM, Almeida SC, Ubaid FK, Maffei F, Jim J. 2010. Amphibia, Anura, Cycloramphidae, Proceratophrys moratoi (Jim and Caramaschi, 1980): Distribution extension and new altitudinal record in state of São Paulo, Brazil. Check List 6:576-578.

426

Ryan MJ. 1991. Sexual selection and communication in frogs. Trends in Ecology \& Evolution $6(11): 351-355$.

São Paulo, 2014. DECRETO $N^{o}$ 60.133, DE 7 DE FEVEREIRO DE 2014. Available in: http://www.al.sp.gov.br/repositorio/legislacao/decreto/2014/decreto-60133-07.02.2014.html

Schwartz JJ. 2001. Call monitoring and interactive playback systems in the study of acoustic interactions among male anurans. In: Ryan MJ, ed. Anuran communication. Washington: Smithsonian Institution Press, 183-204.

Schwartz JJ, Bee MA. 2013. Anuran acoustic signal production in noisy environments. In: Brumm H, ed. Animal Communication and Noise. New York: Springer, 91-132.

Simberloff D. 1986. The proximate causes of extinction. In: D. Raup, D. Jablonski, eds. Patterns and Processes in the History of Life. Berlin: Springer -Verlag, 259-276.

Simões PI, Lima AP, Magnusson WE, Hödl W, Amézquita A. 2008. Acoustic and Madeira River and other potential geological barriers. Biotropica 40:607-614.

Smith MJ, Osborne W, Hunter D. 2003. Geographic variation in the advertisement call structure of Litoria verreauxii (Anura: Hylidae). Copeia 4:750-758.

Stuart SN, Chanson JS, Cox NA, Young BE, Rodrigues ASL, Fischman DL, Waller RW. 2004. Status and trends of amphibian declines and extinctions worldwide. Science 306:1783-1786. 
447 Tobias ML, Evans BJ, Kelley DB. 2011. Evolution of advertisement calls in African clawed $448 \quad$ frogs. Behaviour 148:519-549.

449 Toledo LF, Martins IA, Bruschi DP, Passos MA, Alexandre C, Haddad CFB. 2015a. The anuran 450 calling repertoire in the light of social context. Acta Ethologica 18(2):87-99.

451 Toledo LF, Llusia D, Vieira CA, Corbo M, Márquez R. 2015b. Neither convergence nor 452 divergence in the advertisement call of sympatric congeneric Neotropical treefrogs. 453 Bioacoustics 24(1):31-47.

454 Tozetti A, Toledo LF. 2005. Short-term movement and retreat sites of Leptodactylus 455 labyrinthicus (Anura: Leptodactylidae) during the breeding season: a spool-and-line tracking 456 study. Journal of Herpetology 39(4):640-644.

457 Tsuji-Nishikido BM, Kaefer IL, Freitas FC, Menin M, Lima AP. 2012. Significant but not 458 diagnostic: differentiation through morphology and calls in the Amazonian frogs Allobates $459 \quad$ nidicola and A. masniger. Herpetological Journal 22:105-114.

460 Tucker MA, Gerhardt, HC. 2011. Parallel changes in mate-attracting calls and female 461 preferences in autotriploid tree frogs. Proceedings of The Royal Society B 1-5. 462 Veiga-Menocello AC, Lourenço LB, Strussmann C, Rossa-feres, DC, Andrade GV, Giaretta, 463 AA, Recco-Pimentel SM. 2014. A phylogenetic analysis of Pseudopaludicola (Anura) 464 465 466 providing evidence of progressive chromosome reduction. Zoologica Scripta 43(3):261-272.

Wells KD, Taigen TL. 1986. The effect of social interactions on calling energetics in the gray treefrog (Hyla versicolor). Behavioral Ecology and Sociobiology 19:9-18.

Wilkinson L. 2010. SYSTAT. WIREs. Computational Statistics 2:256-257.

Wong BBM, Cowling ANN, Cunningham RB, Donnelly CF, Cooper PD. 2004. Do temperature and social environment interact to affect call rate in frogs (Crinia signifera)? Austral Ecology 209-214.

Wycherley J, Doran S, Beebee TJC. 2002. Male advertisement call characters as phylogeographic indicators in European water frogs. Biological Journal of the Linnean

474 Yang L, Tan Z, Wang D, Xue L, Guan M, Huang T, Ronghua, L. 2014. Species 475 identification through mitochondrial rRNA genetic analysis. Scientific Reports 4(4089):1-11. 


\section{FIGURES}

477

478 Figure 1. Geographic distribution of Proceratophrys moratoi. State of São Paulo: 1) Avaré, 2)

479 Bauru, 3) Botucatu (type locality - black dot), 4) Itirapina, 5) São Carlos; state of Minas Gerais:

480 6) Ituiutaba, and 7) Uberlândia. Map source: Google Earth.

481

482 483

Figure 2. Call and traits of the frog Proceratophrys moratoi. (a) Waveform of the call. The call is composed of a single pulse-train structure; (b) among-male and (c) within-male coefficients of 484 variation of advertisement call traits. The horizontal continuous line represents the lower limit 485 for dynamic traits (above 12\%) in (b), and the dashed line represents the limit for static acoustic traits (below $5 \%$ of variation) in (c). Dynamic and static traits according to Gerhardt (1991).

Figure 3. Dendrogram of two outgroup species (other Odontophrynidae) and 15 males of Proceratophrys moratoi from different localities resulting from a hierarchical cluster analysis based on similarity in call traits.

491

Figure 4. Haplotype network of Proceratophrys moratoi populations. The size and color of each 493 ellipse indicate the frequency and geographic origin of the individuals. 
Table 1. Acoustic traits (mean $\pm \mathrm{SD}$, range) of seven populations of Proceratophrys moratoi from southeastern Brazil and two close

496 species as outgroups. Data from the population of Botucatu were extracted from Brasileiro, Martins \& Jim (2008).

\begin{tabular}{|c|c|c|c|c|c|c|c|c|}
\hline Groups & $\begin{array}{l}\text { Population } \\
(\mathrm{n}=\text { calls, } \mathrm{M}=\text { males })\end{array}$ & $\begin{array}{l}\text { Frequency } \\
\text { range }(\mathrm{Hz})\end{array}$ & $\begin{array}{l}\text { Minimum } \\
\text { frequency }(\mathrm{Hz})\end{array}$ & $\begin{array}{l}\text { Peak of } \\
\text { dominant } \\
\text { frequency } \\
(\mathrm{Hz})\end{array}$ & $\begin{array}{c}\text { Maximum } \\
\text { frequency }(\mathrm{Hz})\end{array}$ & Call duration (s) & $\begin{array}{l}\text { Pulses per } \\
\text { note }\end{array}$ & $\begin{array}{l}\text { Pulses rate } \\
\qquad(\mathrm{p} / \mathrm{s})\end{array}$ \\
\hline \multirow{14}{*}{ 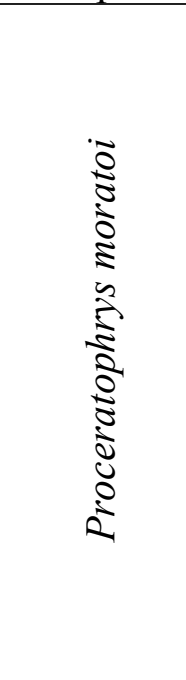 } & Avaré & $291 \pm 20$ & $980 \pm 20$ & $1184 \pm 23$ & $1270 \pm 23$ & $0.297 \pm 0.01$ & $20 \pm 0.9$ & $69 \pm 1.6$ \\
\hline & $(\mathrm{n}=8 ; M=1)$ & $(258-301)$ & $(947-990)$ & $(1163-1206)$ & $(1249-1292)$ & $(0.277-0.315)$ & $(19-22)$ & $(66-71)$ \\
\hline & Bauru & $423 \pm 23$ & $1029 \pm 13$ & $1314 \pm 73$ & $1452 \pm 20$ & $0.227 \pm 0.02$ & $21 \pm 2.2$ & $92 \pm 2.8$ \\
\hline & $(\mathrm{n}=29 ; M=1)$ & $(387-474)$ & $(990-1034)$ & $(1077-1378)$ & $(1421-1464)$ & $(0.160-0.260)$ & $(15-24)$ & $(81-96)$ \\
\hline & Botucatu & 730 & 928 & $1348 \pm 86.6$ & 1659 & $0.207 \pm 17.6$ & $17.5 \pm 1.5$ & . \\
\hline & $(\mathrm{n}=59 ; M=2)$ & & & $(1153-1420)$ & & $(146-238)$ & $(12-20)$ & \\
\hline & Itirapina & $353 \pm 32$ & $1092 \pm 34$ & $1317 \pm 38$ & $1445 \pm 27$ & $0.245 \pm 0.02$ & $23 \pm 2.4$ & $94 \pm 3.2$ \\
\hline & $(\mathrm{n}=78 ; M=3)$ & $(281-388)$ & $(1077-1206)$ & $(1265-1421)$ & $(1406-1507)$ & $(0.183-0.288)$ & $(17-27)$ & $(85-103)$ \\
\hline & Ituiutaba & $433 \pm 66$ & $1129 \pm 57$ & $1440 \pm 26$ & $1562 \pm 19$ & $0.240 \pm 0.01$ & $19 \pm 2$ & $81 \pm 4.9$ \\
\hline & $(\mathrm{n}=54 ; \mathrm{M}=2)$ & $(301-517)$ & $(1077-1249)$ & $(1378-1464)$ & $(1550-1593)$ & $(0.196-0.263)$ & $(14-22)$ & $(67-87)$ \\
\hline & São Carlos & $288 \pm 20$ & $1206 \pm 0$ & $1386 \pm 24$ & $1494 \pm 20$ & $0.307 \pm 0.02$ & $25 \pm 1.4$ & $83 \pm 4.5$ \\
\hline & $(\mathrm{n}=26 ; \mathrm{M}=1)$ & $(258-301)$ & (1206) & $(1335-1464)$ & $(1464-1507)$ & $(0.274-0.382)$ & $(23-28)$ & $(71-89)$ \\
\hline & Uberlândia & $343 \pm 95$ & $1054 \pm 70$ & $1286 \pm 90$ & $1397 \pm 92$ & $0.262 \pm 0.03$ & $18 \pm 1.3$ & $71 \pm 9.5$ \\
\hline & $(\mathrm{n}=141 ; \mathrm{M}=7)$ & $(215-474)$ & $(947-1206)$ & $(1120-1464)$ & $(1249-1550)$ & $(0.186-0.316)$ & $(15-22)$ & $(60-97)$ \\
\hline \multirow{3}{*}{ Outgroup } & $\begin{array}{l}\text { Proceratophrys boiei } \\
(\mathrm{n}=5 ; \mathrm{M}=1)\end{array}$ & $\begin{array}{c}577 \pm 38 \\
(517-603)\end{array}$ & $\begin{array}{c}474 \pm 0 \\
(474)\end{array}$ & $\begin{array}{c}637 \pm 19 \\
(603-646)\end{array}$ & $\begin{array}{c}1051 \pm 38 \\
(990-1077)\end{array}$ & $\begin{array}{c}0.743 \pm 0.05 \\
(0.666-0.795)\end{array}$ & $\begin{array}{l}32 \pm 1.4 \\
(30-34)\end{array}$ & $\begin{array}{c}43.1 \pm 1.1 \\
(42-45)\end{array}$ \\
\hline & Odontophrynus americanus & $287 \pm 24$ & $681 \pm 24$ & $825 \pm 43$ & $968 \pm 38$ & $0.664 \pm 0.10$ & $57 \pm 4.6$ & $86 \pm 9.5$ \\
\hline & $(\mathrm{n}=15 ; \mathrm{M}=2)$ & $(234-328)$ & $(656-703)$ & $(750-890)$ & $(937-1031)$ & $(0.508-0.816)$ & $(49-65)$ & $(79-103)$ \\
\hline
\end{tabular}


498Table 2. Genetic distances (p-distance) based on $16 \mathrm{~S}$ mitochondrial genes between individuals of 499six Proceratophrys moratoi populations in the upper matrix and the respective geographic distance $500($ in $\mathrm{km})$ in the lower matrix.

\begin{tabular}{|c|c|c|c|c|c|c|c|c|}
\hline \multicolumn{7}{|c|}{ Interpopulation variation (\%) } & \multirow{2}{*}{\multicolumn{2}{|c|}{$\begin{array}{l}\text { Intrapopulation } \\
\text { variation (\%) }\end{array}$}} \\
\hline & Itirapina & São Carlos & Bauru & Avaré & Uberlândia & Ituiutaba & & \\
\hline Itirapina & - & 0.2 & 0.4 & 0.2 & 0.2 & 0.0 & Itirapina & 0.0 \\
\hline São Carlos & 21.65 & - & 0.3 & 0.3 & 0.2 & 0.3 & São Carlos & 0.1 \\
\hline Bauru & 114.54 & 116.59 & - & 0.2 & 0.4 & 0.4 & Bauru & 0.2 \\
\hline Avaré & 129.93 & 141.36 & 59 & - & 0.4 & 0.3 & Avaré & 0.5 \\
\hline Uberlândia & 354.97 & 331.88 & 375.50 & 437.27 & - & 0.3 & Uberlândia & 0.3 \\
\hline Ituiutaba & 392.80 & 372.92 & 375.45 & 437.25 & 119.44 & - & Ituiutaba & 0.1 \\
\hline
\end{tabular}


Figure 1

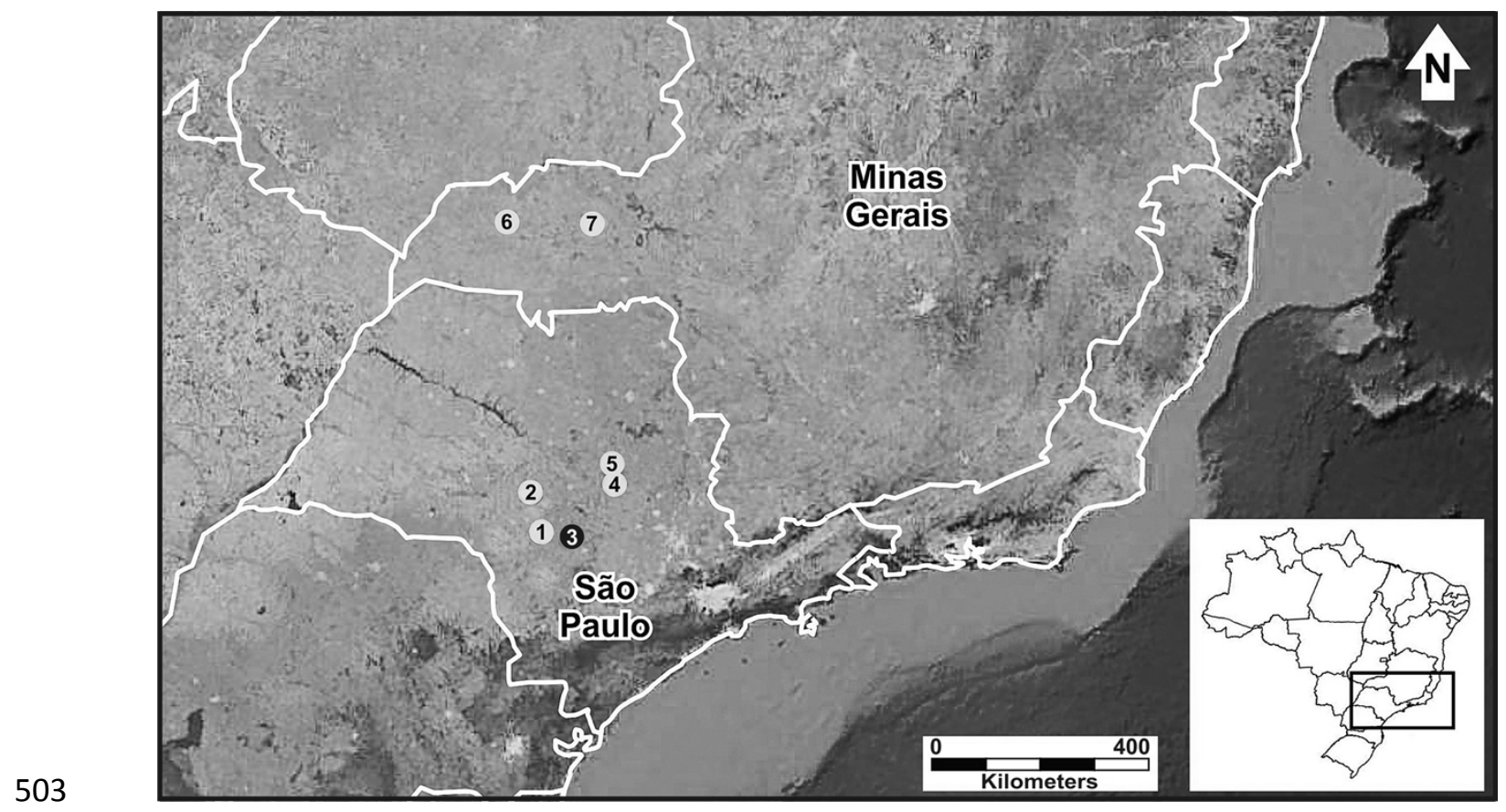


$504 \quad$ Figure 2

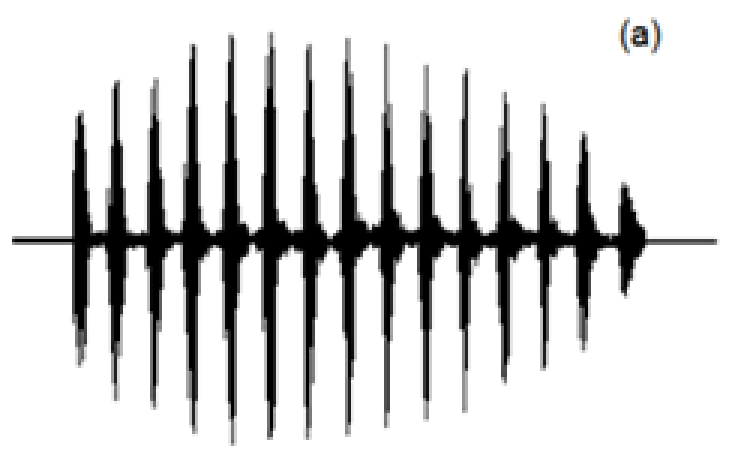

(b)
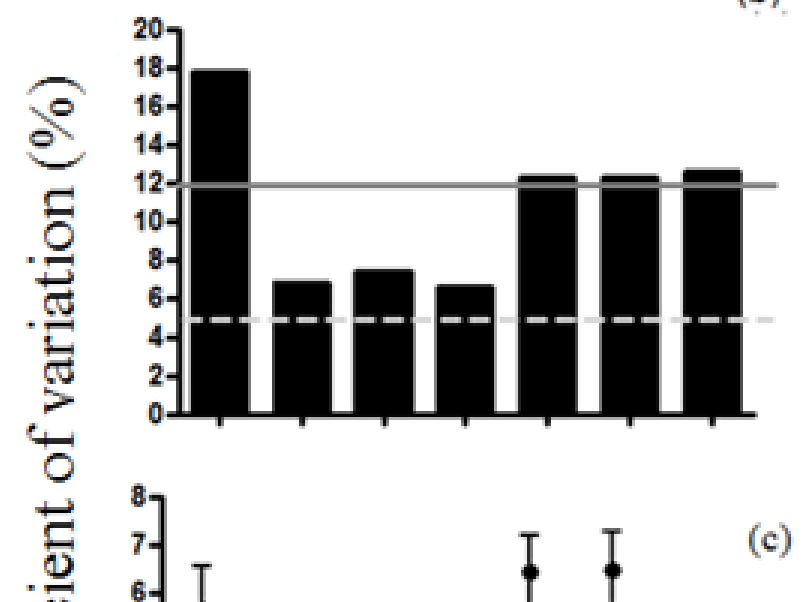
Figure 3

\section{Bray-Curtis index of acoustic similatity $\begin{array}{lllllllll}0.75 & 0.78 & 0.81 & 0.84 & 0.87 & 0.90 & 0.93 & 0.96 & 0.99\end{array}$}

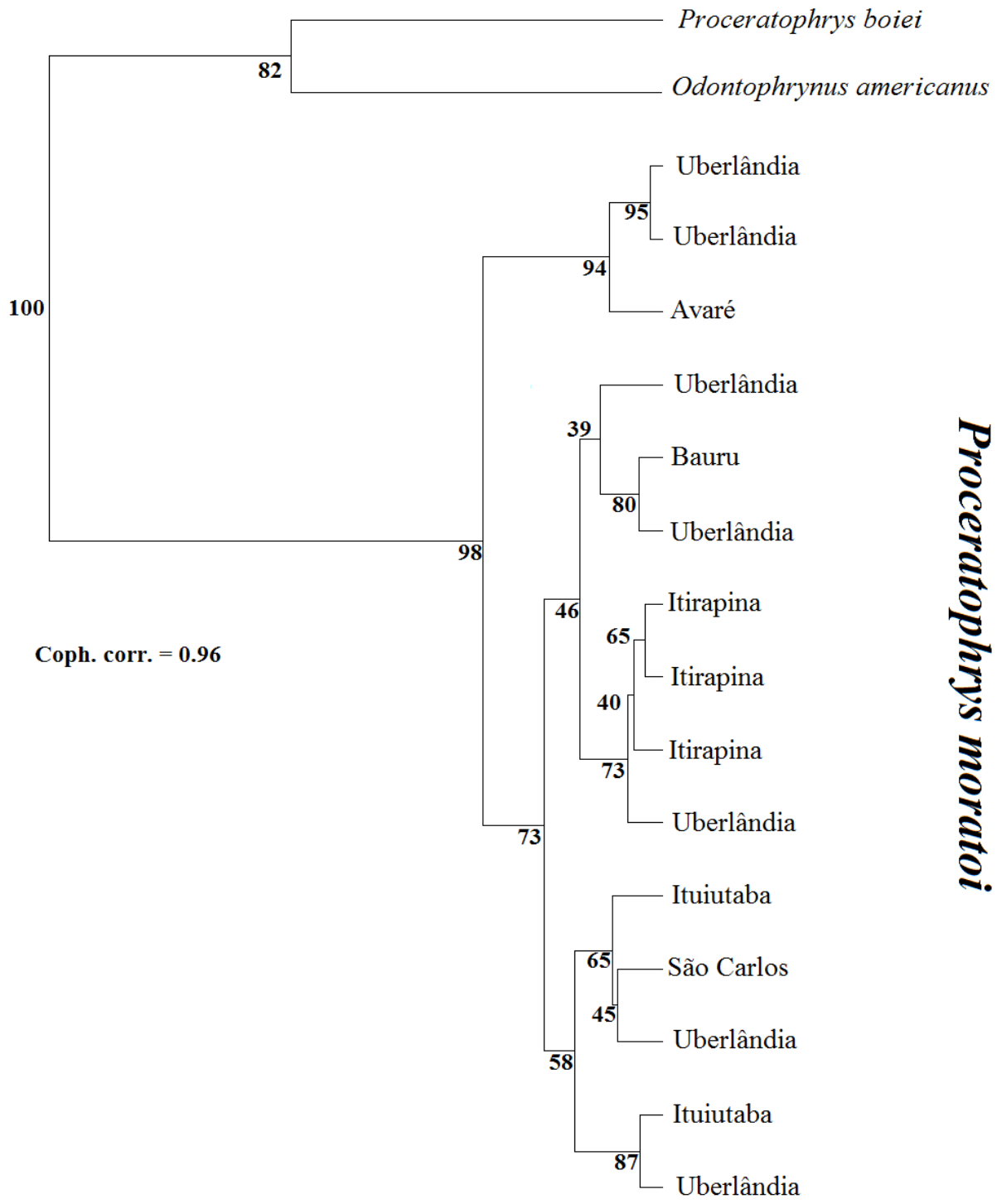


Figure 4

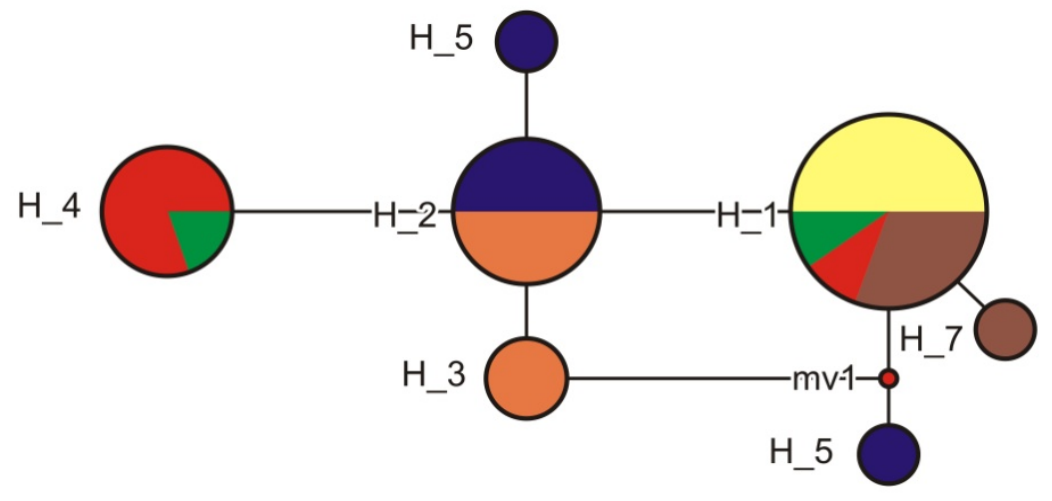

Avaré, SP

- Bauru, SP

Itirapina, SP

Ituiutaba, MG

São Carlos, SP

- Uberlândia, MG

509 